\title{
Teaching and learning sustainability: An assessment of the curriculum content and structure of sustainability degree programs in higher education
}

\author{
David O'Byrne • Weston Dripps • \\ Kimberly A. Nicholas
}

Received: 15 July 2013/Accepted: 1 May 2014/Published online: 15 July 2014

(C) The Author(s) 2014. This article is published with open access at Springerlink.com

\begin{abstract}
Sustainability degree programs in higher education have proliferated with the emergence of sustainability as a recognized academic field. This study evaluated the curricula of English-language programs granting degrees in sustainability by analyzing 27 bachelor's and 27 master's sustainability programs based on their (1) curricular structure, in terms of the proportion of core versus elective courses, (2) breadth of the core courses, which were classified into one of ten disciplinary categories, and (3) specific disciplinary content of core course subjects. We found that core courses made up the majority of both curricula, although bachelor's programs were more flexible than master's. Within these core courses, sustainability and social sciences were found in more than $85 \%$ of both bachelor's and master's programs, as were natural sciences at the bachelor's level. Less than half of sustainability master's programs required a natural science course, which on average made up just $2 \%$ of required course credits. No text was widely used in core sustainability courses. Our findings demonstrate that there is a wide divergence between the content of programs granting degrees in sustainability; many do not appear to be achieving the integration of natural and
\end{abstract}

Handled by Didac Ferrer-Balas, Technical University of Catalonia, Spain.

D. O’Byrne · K. A. Nicholas ( $\square)$

Lund University Center for Sustainability Studies, Lund

University, Box 170, 22100 Lund, Sweden

e-mail: kimberly.nicholas.academic@gmail.com

W. Dripps

Department of Earth and Environmental Sciences, Furman

University, Greenville, SC, USA social sciences proposed in the literature. We believe that some shared foundations between programs is necessary for sustainability to develop into a mature scientific program that is recognizable across universities and understood by academics, employers, and civil society, and is effective in training the next generation of sustainability scholars and scientists.

Keywords Sustainability education - Curriculum design . Sustainability pedagogy · Program design .

Interdisciplinary education

\section{Introduction}

In the past decade, the new academic research program (sensu Khagram et al. 2010) of sustainability has rapidly emerged (Yarime et al. 2012; van der Leeuw et al. 2012), seeking to understand the complex, dynamic interactions between human and environmental systems (Kates et al. 2001; Clark and Dickson 2003). The recent increase in conferences, departments, educational programs, and journals (such as this one) with an explicit focus on sustainability demonstrates the emergence and growing level of establishment of a new academic field. The field of sustainability explicitly aims to integrate environmental, social, and economic dimensions (Komiyama and Takeuchi 2006). To do so, sustainability draws heavily from a wide variety of foundational disciplines (e.g., geography, environmental science, ecology, economics, political science, and sociology) that span academic divisions across natural and social sciences and the arts and humanities, although sustainability is defined more by the problems it addresses rather than the disciplines it employs (Clark 2007). 
Reflecting the growth in the field of sustainability overall, there has been a recent expansion of programs in higher education explicitly focused on sustainability (Vincent et al. 2013). In the US, for example, sustainability degree programs have grown from just one in 2006 to over 140 programs in 2012 (Vincent et al. 2013). These programs have taken diverse approaches to develop inter- and trans-disciplinary, problem-based sustainability degree programs within the current university framework, which tends to favor individual disciplines and departments (Moore 2005a, b; Sibbel 2009; Khagram et al. 2010). For example, some have established a stand-alone School of Sustainability (e.g., Arizona State University), others have embedded the sustainability program within an existing department (e.g., Furman University), and still others have used a multi-disciplinary umbrella approach that shares existing faculty and courses across disciplines (e.g., Baldwin Wallace University). These different models may lead to considerable variations in the curricular structure, design, and content of the program offered.

While the approach to organizational design may vary, there appears to be some consensus on the core concepts that a sustainability program should address in terms of curricular content, including bridging social and natural sciences (Kates et al. 2001; Clark and Dickson 2003; Andersson et al. 2008) and understanding the interconnectedness of social, environmental, and economic systems (Tilbury 1995). There are also suggestions for the learning approach that should be employed to study these concepts, including taking an inter- and trans-disciplinary approach (Martens et al. 2010; Brundiers and Wiek 2013) and engaging with the local context and community needs in the participatory production of scientific knowledge (Brundiers et al. 2010; Yarime et al. 2012).

However, despite the proliferation of academic work to propose definitions and standards for the field of sustainability and its core concepts, less work has been done to evaluate the state and curricular content of existing degree programs in sustainability. The most comprehensive sustainability curriculum assessments have been done for Australia, where Sherren $(2005,2006,2008)$ evaluated the required courses for that country's environmental programs more generally, including nine programs granting degrees in sustainability. There have also been reviews that considered the presence of sustainability concepts within specific disciplines in certain geographic areas, for example, engineering in Europe (Segalàs et al. 2008) and the built environment in Asia-Pacific (Iyer-Raniga and Andamon 2012), but to date there has been no international analysis of the curriculum design, structure, and content of higher education degree programs in sustainability taught in English.

This study set out to assess the curriculum structure and content of higher education programs offering degrees in sustainability by analyzing those programs that explicitly identify themselves and their graduates as representing the field of sustainability (which we call "sustainability focused" programs), in contrast to programs that incorporate aspects of sustainability within an existing discipline (e.g., sustainability management). Such an assessment allows us to examine the diversity and coherence of the field and to compare the content actually being taught with what is proposed in the literature as a core curriculum for sustainability. If, for example, the majority of sustainability degree programs do not include coursework in economics, this deficit has implications for how sustainability, or more precisely degrees in sustainability, are percieved.

In an effort to characterize the curricula of current bachelor's and master's degree programs in sustainability, this study analyzed 27 bachelor's and 27 master's sustainability programs based on their (1) curricular structure, in terms of the proportion of core versus elective courses, (2) breadth of the core courses, which were classified into one of ten disciplinary categories, and (3) specific disciplinary content of core course subjects. The overall intent of the study was to assess how sustainability programs are structured, what courses and content are being taught in these programs, and the degree of similarity among the different programs with regards to content and structure. Analysis of the curricular structure allows for comparisons of program design and content. The classification and division of core courses among disciplinary categories quantifies the relative importance of each category within sustainability curricula. Further classification of the courses into subjects within each category reflects the specific content that constitutes these programs. As such, this study provides insight into the training of sustainability graduates and the degree of the alignment between the current design and content of sustainability programs with the core concepts of sustainability. Furthermore, the study provides a summary and snapshot of what is currently being institutionalized under the name of sustainability, a measure of the coherence of the discipline, and a means to assess how well the curriculum matches the theory, all of which are important for guiding the future development of sustainability programs.

\section{Methods}

\section{Program selection}

To begin our analysis, we selected bachelor's and master's degree programs in sustainability to include in this study from the inventory of self-reported programs maintained by the Journal for Sustainability: Science, Practice and Policy (SSPP 2012). This database is the largest and most 
comprehensive list of sustainability degree programs of which we are aware. As of January 2012, when we chose programs to evaluate, the database had over 200 programs listed. For the assessment we included only programs from the database that offered a bachelor's or master's degree including the words "sustainable" or "sustainability," as we wanted to assess programs that explicitly placed themselves within the emerging field of sustainability, and we believed these programs would be most closely aligned with the literature on sustainability in theory and in educational practice.This approach largely correlates with the classification of Sustainability Degrees by Vincent et al. (2013).

We acknowledge the large number of interdisciplinary and sustainability-related programs in higher education (e.g., environmental science, earth systems, environmental studies, public policy) and realize a broad curricular examination of these programs might be useful. However, we intentionally limited this analysis to programs that included "sustainable" or "sustainability" in the degree name as we felt these programs were clearly and explicitly designed and marketed as sustainability programs, and should, therefore, be most closely aligned with the literature on sustainability in theory and in educational practice, and exemplary of what sustainability currently means in higher education. We realize these criteria will exclude some well-established sustainability-related programs, but in the end decided to use criteria that do not require our subjective evaluation of whether a program that does not mention or only makes indirect reference to sustainability is a valid sustainability degree.

Having selected the programs for inclusion in the study, we compiled a consistent database that included information about the university's demographics and the hosting or home department for the program (derived from University web pages), and the program descriptions, degree requirements, and course structure and subjects (derived from program web pages). In this study, university degrees consist of one "program" of education comprised of a number of "courses." Courses are individual units for which credits are awarded; a specified number of credits are required to complete the program and receive the degree.

\section{Program analysis}

First, to assess each program's curricular structure, we categorized the program's courses by their degree of "requiredness" as reported on the program web page. Core courses, which constitute the foundation of each program, were classified as either "required" (mandatory for all students to graduate) or "option" (selected from two to four specified courses). Elective courses, on the other hand, were classified as either "restricted" (chosen by the student from a wide-ranging, but finite specified list) or "free" (either chosen from a very large, unspecified pool, or from any course at the university). The meaning and assignment of course credits varied among programs, universities, and countries. To be able to make valid comparisons between programs, we assessed the relative proportion of required, option or elective courses in programs as a percentage of the overall credits required for completion of the program.

Second, we analyzed the breadth of the core (required and option) courses in each program by classifying each core course into one of ten disciplinary categories that we developed (Table 1), using coding based on the course title and course description. The coding process was refined iteratively until we had clear, unambiguous categorizations for each course (Fig. 1). We focused only on the core courses as they were seen as most vital to understanding the curricular foundations of these programs.

The first five disciplinary categories we used built on three standard models for the classification of disciplines in Australia, the United Kingdom, and the United States, resulting in categories for (1) Natural Sciences, (2) Social Sciences, (3) Engineering, (4) Business, and (5) Arts and Humanities (Australian Bureau of Statistics 1998; Higher Education Statistics Agency 2012; National Centre for Education Statistics 2012). We augmented this framework by adding five categories that captured the range of courses we found in sustainability degree programs: two categories specifically for sustainability courses [(6) General Sustainability and (7) Applied Sustainability] and three categories for research and applied work [(8) Methods, (9) Research, and (10) Applied Work]. Detailed titles and definitions of the 10 categories are shown in Table 1 . Once we categorized the courses, we looked at the relative importance of different disciplinary categories required within programs based on the proportion of academic credits assigned for each core course, expressed as a percentage of the total core course credit requirements for that program.

Third, we compiled a list of between two and sixteen general course subjects within each disciplinary category (Table 1) and assigned every core course in every program to one of these course subjects to examine the distribution of subject material between programs. The number and variety of restricted and free electives were vast, and detailed course descriptions were often unavailable. Subjects were, therefore, coded for only the core courses, based on an analysis of their course titles and descriptions (Fig. 1). If there was a lack of agreement or the subject designation was unclear based on the course title and a general reading of the description, the course description was further examined for keywords in topic sentences, i.e., subject names or related concepts. If there was more than one subject inferred or stated in the description, emphasis or a dominant subject was determined. In the case of the five traditional disciplinary categories, courses were 
Table 1 The ten disciplinary categories used in this study for classifying sustainability programs in higher education, the definitions we used to classify courses, and the course subjects that made up each category. The first five categories were taken from existing classification systems (Australian Bureau of Statistics 1998; Higher
Education Statistics Agency 2012; National Centre for Education Statistics 2012), while the last five categories were added by us to capture the structure of sustainability programs, using an iterative process (shown in Fig. 1) to develop categories based on courses in the sustainability degree programs we analyzed

\begin{tabular}{|c|c|c|}
\hline $\begin{array}{l}\text { Disciplinary } \\
\text { category }\end{array}$ & Definition & Course subjects \\
\hline $\begin{array}{l}\text { Natural } \\
\text { Sciences }\end{array}$ & $\begin{array}{l}\text { Sciences that focus on processes in the physical/natural as } \\
\text { opposed to the human/social world, and mathematics }\end{array}$ & $\begin{array}{l}\text { Atmospheric Science, Biology, Chemistry, Earth Science, } \\
\text { Ecology, Environmental Science, Geology, Hydrology, } \\
\text { Mathematics, Physical Geography, Physics }\end{array}$ \\
\hline $\begin{array}{l}\text { Social } \\
\text { Sciences }\end{array}$ & $\begin{array}{l}\text { Sciences that focus on human behavior and social patterns and } \\
\text { structures }\end{array}$ & $\begin{array}{l}\text { Anthropology, Communications, Conflict and Peace Studies, } \\
\text { Cultural Studies, Demography, Development, Economics, } \\
\text { Education, Environmental Sociology, Justice and Equity } \\
\text { Studies, Law, Policy and Governance, Psychology, } \\
\text { Sociology, Social Theory, Urban Sociology }\end{array}$ \\
\hline Engineering & $\begin{array}{l}\text { Identified by reference to engineering, design, machines, } \\
\text { systems or technology. Distinguished from applied } \\
\text { sustainability by reference to these aspects of issues or } \\
\text { problems alone, without social, environmental, political, or } \\
\text { other context }\end{array}$ & $\begin{array}{l}\text { Architecture, Design for Sustainability, Energy Systems, } \\
\text { Engineering, Information Technology, Planning, Transport }\end{array}$ \\
\hline Business & $\begin{array}{l}\text { Distinguished from social sciences by a focus on human } \\
\text { organizations, especially businesses and management, } \\
\text { including decision making and strategy }\end{array}$ & $\begin{array}{l}\text { Accounting, Assessment, Business Studies, Decision-Making, } \\
\text { Finance, Leadership, Management, Marketing, NGOs and } \\
\text { Advocacy, Organizational Studies, Participatory Processes, } \\
\text { Sustainable Business Practices }\end{array}$ \\
\hline $\begin{array}{l}\text { Arts and } \\
\text { Humanities }\end{array}$ & $\begin{array}{l}\text { Studies that focus on the processes and productions of human } \\
\text { culture }\end{array}$ & $\begin{array}{l}\text { Composition, Ethics, History, Humanities, Literature, } \\
\text { Philosophy, Religious Studies }\end{array}$ \\
\hline $\begin{array}{l}\text { General } \\
\text { Sustainability }\end{array}$ & $\begin{array}{l}\text { Identified by use of the words "sustainability" and } \\
\text { "interdisciplinary", and by reference to many disciplines. } \\
\text { Often referred to environmental, social, and economic } \\
\text { systems }\end{array}$ & $\begin{array}{l}\text { Introduction to Sustainability, Sustainable Development, } \\
\text { Sustainability Seminar, Systems Thinking }\end{array}$ \\
\hline $\begin{array}{l}\text { Applied } \\
\text { Sustainability }\end{array}$ & $\begin{array}{l}\text { Identified when resources or problems appeared in course } \\
\text { descriptions in the context of environmental, social, and } \\
\text { economic aspects or impacts. Distinguished from other } \\
\text { categories by mention of two or more of the following: } \\
\text { social, ecological, economic, political, technical; and } \\
\text { impacts, effects, or aspects }\end{array}$ & $\begin{array}{l}\text { Agriculture, Climate, Ecosystems, Energy, Enterprise, } \\
\text { Fisheries, Food, Forests, Health, Industry, Land, Pollution, } \\
\text { Rural, Sustainable Resource Management, Transport, } \\
\text { Urban, Waste, Water }\end{array}$ \\
\hline Methods & $\begin{array}{l}\text { General training in research methods, or a focus on specific } \\
\text { tools and modeling }\end{array}$ & $\begin{array}{l}\text { Geographical Information Systems (GIS), Life Cycle Analysis } \\
\text { (LCA), General Modeling, General Research Methods, } \\
\text { Statistics, Quantitative Methods }\end{array}$ \\
\hline Research & $\begin{array}{l}\text { Systematic work with the aim of producing new knowledge. } \\
\text { Often involving the production of an academic paper }\end{array}$ & Thesis, Research Project \\
\hline Applied Work & $\begin{array}{l}\text { "Real-world" education for sustainability (Brundiers et al. } \\
\text { 2010). Distinguished from Research by active engagement } \\
\text { with actors, organizations, or communities outside of the } \\
\text { classroom. Focus on problem solving, not necessarily the } \\
\text { production of knowledge }\end{array}$ & Applied Project, Fieldwork, Internship \\
\hline
\end{tabular}

assigned to recognized subject areas following existing classification systems (Australian Bureau of Statistics 1998; Higher Education Statistics Agency 2012; National Centre for Education Statistics 2012). In the case of the five disciplinary categories we added, the process involved multiple readings of all course titles and descriptions in these categories and the iterative development of new subject areas (Fig. 1). Finally, to see if there was a common body of literature being drawn upon to teach students the central concepts of sustainability, we requested reading lists via e-mail to the instructor for all core sustainability courses. The syllabi received were examined for commonalities across programs.

\section{Results}

In total, we identified and evaluated 54 programs (27 bachelor's and 27 master's degree programs) that met our selection criteria. The database contained over 200 entries, with 114 programs that included the word "sustainability" or "sustainable". After removing those programs that had 


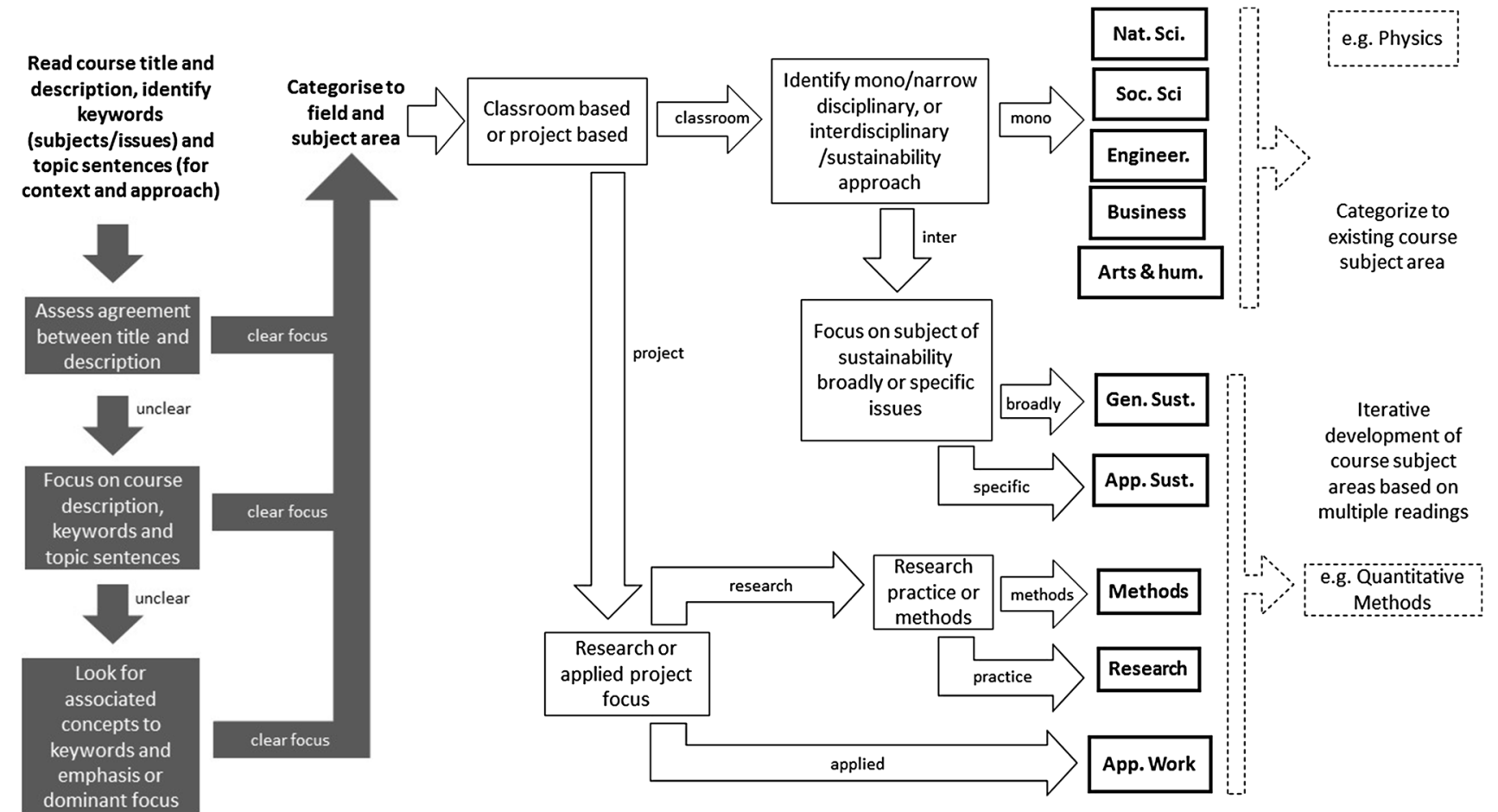

Fig. 1 Process for first reading course descriptions to gather enough information for disciplinary categorization (dark gray boxes), and then categorizing individual courses once sufficient information had

insufficient information on their website to permit analysis, and those that on closer examination did not fulfil the original criteria (e.g., was not a bachelor's or master's degree), the sample was reduced to 87 . Finally, on qualitative review of the program websites, 54 programs were selected from these as focusing on sustainability, rather than incorporating aspects of sustainability within an existing discipline, and having enough information for the curricular analysis. The majority of programs that met our criteria for inclusion are located in the United States and the United Kingdom (Table 2). The universities represented range from small private institutions with a few thousand students to large public research universities with over 50,000 students. Programs are offered through undergraduate departments within the natural sciences, social sciences, and/or the arts; interdepartmental umbrella programs; separate academic institutes for sustainability; and graduate schools. Master's programs require a bachelor's degree and documents such as academic transcripts, resumes, and scores on standardized tests for admission, but typically do not require any specific disciplinary background or course prerequisites.

\section{Curricular structure}

The percentage of credits of core (required and option) versus elective (restricted and free electives) courses varied been gathered to classify courses into one of ten disciplinary categories (white boxes with heavy outlines on the right)

widely among programs at both the bachelor's and master's level (Fig. 2). All degree programs assessed had greater than $40 \%$ of their credits as core course credits, although the bachelor's programs were, on average, more flexible than the master's programs, with a higher percentage of the credits as option and elective courses. Bachelor's programs ranged from having roughly $50 \%$ core credits to one program that was entirely required courses. Eight bachelor's programs (30\% of the total) were comprised entirely of core courses with no electives. Similarly, the master's programs included one program with less than half its credits in core courses, but the majority (16 programs, or $59 \%$ ) consisted entirely of core courses with no electives. In terms of required courses, $15 \%$ of the bachelor's programs (4 programs) had more than $75 \%$ required courses, compared to $41 \%$ of the master's programs (11 programs).

\section{Core course breadth}

\section{Required courses}

Focusing now on the course credits contributed by required courses, bachelor's programs were dominated by the natural sciences ( $24 \%$ of required course credits on average across programs) and general sustainability (23\%), followed by social sciences $(15 \%)$ and methods (10\%) 
Table 2 Programs in sustainability included in this analysis at the bachelor's $(N=27)$ and master's $(N=27)$ level. The type of degree granted (bachelor or master of arts or sciences) is listed where it could be determined from program websites

\begin{tabular}{|c|c|c|c|c|}
\hline University & Program title & Degree-Granting Institution & Location & Country \\
\hline \multicolumn{5}{|l|}{ Bachelor's Programs } \\
\hline Acadia University & $\begin{array}{l}\text { BA in Environmental and } \\
\text { Sustainability Studies }\end{array}$ & College of Arts & $\begin{array}{l}\text { Wolfville, Nova } \\
\text { Scotia }\end{array}$ & Canada \\
\hline $\begin{array}{l}\text { Appalachian State } \\
\text { University }\end{array}$ & BA in Sustainable Development* & University College & $\begin{array}{l}\text { Boone, North } \\
\text { Carolina }\end{array}$ & USA \\
\hline Arizona State University & BA in Sustainability*a & School of Sustainability & Tempe, Arizona & USA \\
\hline Arizona State University & BSc in Sustainability*a & School of Sustainability & Tempe, Arizona & USA \\
\hline Baldwin Wallace College & BA in Sustainability* & Multiple Faculty & Berea, Ohio & USA \\
\hline Daemen College & $\begin{array}{l}\text { BA in Global and Local } \\
\text { Sustainability }\end{array}$ & Division of Arts and Sciences & Amherst, New York & USA \\
\hline Drew University & $\begin{array}{l}\text { Environmental Studies and } \\
\text { Sustainability Major* }\end{array}$ & $\begin{array}{l}\text { Environmental Studies and } \\
\text { Sustainability Department }\end{array}$ & Madison, New Jersey & USA \\
\hline $\begin{array}{l}\text { Eastern Mennonite } \\
\text { University }\end{array}$ & $\begin{array}{l}\text { Environmental Sustainability } \\
\text { Major }\end{array}$ & Biology Department & $\begin{array}{l}\text { Harrisonburg, } \\
\text { Virginia }\end{array}$ & USA \\
\hline Furman University & BSc in Sustainability Science* & $\begin{array}{l}\text { Department of Earth and } \\
\text { Environmental Sciences }\end{array}$ & $\begin{array}{l}\text { Greenville, South } \\
\text { Carolina }\end{array}$ & USA \\
\hline Johns Hopkins University & $\begin{array}{l}\text { BA Global Environmental Change } \\
\text { and Sustainability }\end{array}$ & School of Arts and Sciences & Baltimore, Maryland & USA \\
\hline Kean University & BS in Sustainability Science* & Center for Sustainability Studies & Hillside, New Jersey & USA \\
\hline McGill University & $\begin{array}{l}\text { BA and BSc Interfaculty Major: } \\
\text { Sustainability, Science and } \\
\text { Society* }\end{array}$ & Interfaculty Degree & Montreal, Quebec & Canada \\
\hline Meredith College & $\begin{array}{l}\text { BA in Environmental } \\
\text { Sustainability }\end{array}$ & $\begin{array}{l}\text { Natural and Mathematical } \\
\text { Sciences }\end{array}$ & $\begin{array}{l}\text { Raleigh, North } \\
\text { Carolina }\end{array}$ & USA \\
\hline Messiah College & BA in Sustainability Studies & $\begin{array}{l}\text { Department of Sociology, } \\
\text { Anthropology and Criminal } \\
\text { Justice }\end{array}$ & $\begin{array}{l}\text { Grantham, } \\
\text { Pennsylvania }\end{array}$ & USA \\
\hline Mountain State University & $\begin{array}{l}\text { BS in Environmental } \\
\text { Sustainability }\end{array}$ & Department of Arts and Sciences & $\begin{array}{l}\text { Beckley, West } \\
\text { Virginia }\end{array}$ & USA \\
\hline Murdoch University & $\begin{array}{l}\text { BSc in Sustainability Science } \\
(\mathrm{SS})^{* \mathrm{~b}}\end{array}$ & $\begin{array}{l}\text { School of Social Sciences and } \\
\text { Humanities }\end{array}$ & Perth & Australia \\
\hline Murdoch University & $\begin{array}{l}\text { BA in Sustainable Development } \\
(\mathrm{SD})^{* \mathrm{~b}}\end{array}$ & $\begin{array}{l}\text { School of Social Sciences and } \\
\text { Humanities }\end{array}$ & Perth & Australia \\
\hline New Haven University & BS in Sustainability Studies & College of Engineering & $\begin{array}{l}\text { New Haven, } \\
\text { Connecticut }\end{array}$ & USA \\
\hline Philadelphia University & $\begin{array}{l}\text { BA in Environmental } \\
\text { Sustainability* }\end{array}$ & $\begin{array}{l}\text { College of Science, Health and } \\
\text { Liberal Arts }\end{array}$ & $\begin{array}{l}\text { Philadelphia, } \\
\text { Pennsylvania }\end{array}$ & USA \\
\hline Roosevelt University & BA in Sustainability Studies* & College of Professional Studies & Chicago, Illinois & USA \\
\hline $\begin{array}{l}\text { San Francisco State } \\
\text { University }\end{array}$ & $\begin{array}{l}\text { BA in Environmental Studies } \\
\text { (Concentration in Sustainability } \\
\text { and Social Justice)* }\end{array}$ & $\begin{array}{l}\text { College of Health and Social } \\
\text { Sciences }\end{array}$ & $\begin{array}{l}\text { San Francisco, } \\
\text { California }\end{array}$ & USA \\
\hline St. Andrews University & BSc in Sustainable Development* & $\begin{array}{l}\text { Department of Geography and } \\
\text { Geosciences }\end{array}$ & St. Andrews & UK \\
\hline Stony Brook University & BA in Sustainability Studies & Sustainability Studies Program & $\begin{array}{l}\text { Stony Brook, New } \\
\text { York }\end{array}$ & USA \\
\hline University of Oklahoma & $\begin{array}{l}\text { BA in Environmental } \\
\text { Sustainability*c }\end{array}$ & $\begin{array}{l}\text { College of Atmospheric and } \\
\text { Geologic Sciences }\end{array}$ & Norman, Oklahoma & USA \\
\hline University of Oklahoma & $\begin{array}{l}\text { BSc in Environmental } \\
\text { Sustainability*c }\end{array}$ & $\begin{array}{l}\text { College of Atmospheric and } \\
\text { Geologic Sciences }\end{array}$ & Norman, Oklahoma & USA \\
\hline $\begin{array}{l}\text { Washington University in } \\
\text { St. Louis }\end{array}$ & BSc in Sustainability* & Department of Arts and Sciences & St. Louis, Missouri & USA \\
\hline $\begin{array}{l}\text { Western New England } \\
\text { University }\end{array}$ & Sustainability Major* & College of Arts and Sciences & $\begin{array}{l}\text { Springfield, } \\
\text { Massachusetts }\end{array}$ & USA \\
\hline
\end{tabular}


Table 2 continued

\begin{tabular}{|c|c|c|c|c|}
\hline University & Program title & Degree-Granting Institution & Location & Country \\
\hline \multicolumn{5}{|l|}{ Master's Programs } \\
\hline $\begin{array}{l}\text { Antioch University New } \\
\text { England }\end{array}$ & $\begin{array}{l}\text { MSc in Environmental Studies, } \\
\text { Concentration in Advocacy for } \\
\text { Social Justice \& Sustainability } \\
\text { and Sustainable Development } \\
\text { and Climate Change }\end{array}$ & $\begin{array}{l}\text { Department of Environmental } \\
\text { Studies }\end{array}$ & $\begin{array}{r}\text { Keene, New } \\
\text { Hampshire }\end{array}$ & USA \\
\hline Arizona State University & MA in Sustainability*d & School of Sustainability & Tempe, Arizona & USA \\
\hline Arizona State University & MSc in Sustainability*d & School of Sustainability & Tempe, Arizona & USA \\
\hline Lipscomb University & Master of Science in Sustainability & Institute for Sustainable Practice & Nashville, Tennessee & USA \\
\hline Lund University & $\begin{array}{l}\text { Lund University International } \\
\text { Master's Programme in } \\
\text { Environmental Studies and } \\
\text { Sustainability Science* }\end{array}$ & Centre for Sustainability Studies & Lund & Sweden \\
\hline Maastricht University & $\begin{array}{l}\text { Master of Sustainability Science } \\
\text { and Policy }\end{array}$ & $\begin{array}{l}\text { International Centre for Integrated } \\
\text { Assessment and Sustainable } \\
\text { Development }\end{array}$ & Maastricht & $\begin{array}{l}\text { The } \\
\text { Netherlands }\end{array}$ \\
\hline Murdoch University & $\begin{array}{l}\text { MA in Ecologically Sustainable } \\
\text { Development* }\end{array}$ & $\begin{array}{l}\text { School of Social Science and } \\
\text { Humanities }\end{array}$ & Perth & Australia \\
\hline Northern Arizona University & $\begin{array}{l}\text { Master in Sustainable } \\
\text { Communities }\end{array}$ & $\begin{array}{l}\text { College of Social and Behavioural } \\
\text { Science }\end{array}$ & Flagstaff, Arizona & USA \\
\hline Ramapo College & $\begin{array}{l}\text { Master of Arts in Sustainability } \\
\text { Studies* }\end{array}$ & School of Graduate Studies & Mahwah, New Jersey & USA \\
\hline St. Louis University & Master of Sustainability & Interdepartmental Collaboration & St. Louis, Missouri & USA \\
\hline Stockholm University & $\begin{array}{l}\text { Master of Social Ecological } \\
\text { Resilience for Sustainable } \\
\text { Development* }\end{array}$ & $\begin{array}{l}\text { Department of Biology and } \\
\text { Stockholm Resilience Centre }\end{array}$ & Stockholm & Sweden \\
\hline University of Edinburgh & $\begin{array}{l}\text { MSc in Environmental } \\
\text { Sustainability* }\end{array}$ & School of Geosciences & Edinburgh & UK \\
\hline University of Leeds & $\begin{array}{l}\text { MSc in Sustainability (with a } \\
\text { concentration in Consulting and } \\
\text { Project Management }[\mathrm{CPR}])^{* \mathrm{~d}}\end{array}$ & School of Earth and Environment & Leeds & UK \\
\hline University of Leeds & $\begin{array}{l}\text { MSc in Sustainability (with a } \\
\text { concentration in Environment } \\
\text { and Development }[\mathrm{ED}])^{* \mathrm{~d}}\end{array}$ & School of Earth and Environment & Leeds & UK \\
\hline University of Leeds & $\begin{array}{l}\text { MSc in Sustainability (with a } \\
\text { concentration in Ecological } \\
\text { Economics }[\mathrm{EE}])^{* \mathrm{~d}}\end{array}$ & School of Earth and Environment & Leeds & UK \\
\hline University of Leeds & $\begin{array}{l}\text { MSc in Sustainability (with a } \\
\text { concentration in Business } \\
\text { Environment and Corporate } \\
\text { Responsibility [CSR])*d }\end{array}$ & School of Earth and Environment & Leeds & UK \\
\hline University of Leeds & $\begin{array}{l}\text { MSc in Sustainability (with a } \\
\text { concentration in Environmental } \\
\text { Politics and Policy [EPP])*d }\end{array}$ & School of Earth and Environment & Leeds & UK \\
\hline University of Leeds & $\begin{array}{l}\text { MSc in Sustainability (with a } \\
\text { concentration in Climate Change } \\
[\mathrm{CC}])^{* \mathrm{~d}}\end{array}$ & School of Earth and Environment & Leeds & UK \\
\hline University of Leeds & $\begin{array}{l}\text { MSc in Sustainability (with a } \\
\text { concentration in Transport }[\mathrm{T}])^{* \mathrm{~d}}\end{array}$ & School of Earth and Environment & Leeds & UK \\
\hline University of South Florida & $\begin{array}{l}\text { Master of Arts in Global } \\
\text { Sustainability }\end{array}$ & School of Global Sustainability & Tampa, Florida & USA \\
\hline University of Strathclyde & $\begin{array}{l}\text { MSc in Sustainability and } \\
\text { Environmental Studies }\end{array}$ & $\begin{array}{l}\text { Department of Civil and } \\
\text { Environmental Engineering }\end{array}$ & Glasgow & UK \\
\hline $\begin{array}{l}\text { University of Texas at } \\
\text { Arlington }\end{array}$ & $\begin{array}{l}\text { Master of Science in } \\
\text { Interdisciplinary Studies- } \\
\text { Sustainability Track }\end{array}$ & $\begin{array}{l}\text { School of Urban and Public } \\
\text { Affairs }\end{array}$ & Arlington, Texas & USA \\
\hline
\end{tabular}


Table 2 continued

\begin{tabular}{|c|c|c|c|c|}
\hline University & Program title & Degree-Granting Institution & Location & Country \\
\hline University of Tokyo & Master of Sustainability Science & $\begin{array}{l}\text { Graduate School of Frontier } \\
\text { Sciences }\end{array}$ & Tokyo & Japan \\
\hline Utrecht University & $\begin{array}{l}\text { Master's in Sustainable } \\
\text { Development, Global Change } \\
\text { and Ecosystems (GCE) }\end{array}$ & Faculty of Geosciences & Utrecht & $\begin{array}{l}\text { The } \\
\text { Netherlands }\end{array}$ \\
\hline Utrecht University & $\begin{array}{l}\text { Master's in Sustainable } \\
\text { Development, Energy and } \\
\text { Resources (SDE) }\end{array}$ & Faculty of Geosciences & Utrecht & $\begin{array}{l}\text { The } \\
\text { Netherlands }\end{array}$ \\
\hline Utrecht University & $\begin{array}{l}\text { Master's in Sustainable } \\
\text { Development, Environmental } \\
\text { Governance (EG) }\end{array}$ & Faculty of Geosciences & Utrecht & $\begin{array}{l}\text { The } \\
\text { Netherlands }\end{array}$ \\
\hline Utrecht University & $\begin{array}{l}\text { Master's in Sustainable } \\
\text { Development, International } \\
\text { Development (ID) }\end{array}$ & Faculty of Geosciences & Utrecht & $\begin{array}{l}\text { The } \\
\text { Netherlands }\end{array}$ \\
\hline
\end{tabular}

Abbreviations for program titles are given in parentheses or brackets where they are later necessary to distinguish multiple programs from the same university. Programs marked with $*$ contributed syllabi with reading lists for analysis of the core sustainability courses. The $*$ symbol followed by a letter indicates where the same core sustainability course was taught in more than one degree program

(Fig. 3). Within the master's programs, required course credits were primarily research $(28 \%$ of the required course credits) and general sustainability courses $(20 \%)$, followed by social sciences $(13 \%)$, methods $(12 \%)$, and applied work (11\%) (Fig. 3). On average, the natural sciences comprised only $2 \%$ of the total required credits in the master's programs, and the majority of the master's programs $(85 \%)$ had no natural science courses as part of their required content (data not shown). At the bachelor's and master's levels, respectively, arts and humanities (6, $1 \%$ ), engineering $(1,1 \%)$, and business $(3,4 \%)$ courses contributed only small portions of the required program content (Fig. 3).

\section{Core courses}

For this analysis, we used a count of the number of disciplinary categories covered by the core (required plus option) courses within each program. On average, both bachelor's and master's programs featured core courses in more than 6 of the 10 different disciplinary categories, which shows a high degree of disciplinary variety at both levels. However, there was no one disciplinary category of the ten included in the core curriculum by all programs at either the bachelor's or master's level, including either of the sustainability categories. The majority of bachelor's programs featured core courses in natural sciences $(96 \%$ of programs), general sustainability ( $93 \%$ ), and the social sciences $(85 \%)$ (Fig. 4a), while the master's programs featured courses in general sustainability ( $93 \%$ ), the social sciences (89 \%), and research (89\%) (Fig. 4b). Considerably more programs at the master's ( $78 \%$ ) compared to the bachelor's (56\%) level had core courses focused on applied work. Although business courses made up a very small portion of the required course curriculum in both levels of programs, they were common as option courses, especially at the master's level.

There are several notable differences between the core course offerings at the bachelor's versus the master's level. The most striking disparity is that $96 \%$ of bachelor's programs included a natural science course in their core offerings, while only $44 \%$ of master's programs did (Fig. 4). In addition, $56 \%$ of bachelor's programs had an arts and humanities course in their core offerings, compared to only $22 \%$ of the master's programs (Fig. 4). In contrast, only $33 \%$ of the bachelor's programs had a research course component within their core, while $89 \%$ of master's programs featured research.

Core course subjects

Among the core courses, each disciplinary category contained a number of course subject areas (Table 1), with many categories dominated by one or two common subjects (Fig. 4). In the sustainability category, an introductory sustainability course was present in $81 \%$ of bachelor's and $85 \%$ of master's programs. In the core course category of applied sustainability, the topics offered ranged widely (Table 1), but the urban sustainability and energy core course subject areas were the most common among bachelor's programs (present in 41 and $33 \%$ of the programs respectively), and the climate (41\%) and enterprise (37\%) core course subject areas were the most common among the master's programs. Seven master's programs with a core course in applied sustainability focusing on climate contributes to the high weighting for this subject at the 
Fig. 2 The percentage of each bachelor's (a) and master's (b) program consisting of required, option, restricted and free elective courses. Data are taken from program summaries on program websites, and ordered by level of core (required + option credits) course credits. Different programs award credits according to different systems, so programs are compared in terms of percentage of total credits. Institution name (e.g., University (U) or College (C)), degree type (e.g., BA vs. BSc), and program name for universities with multiple degree programs are abbreviated from Table 2 a

\section{Course Structure of Bachelor's Programmes}

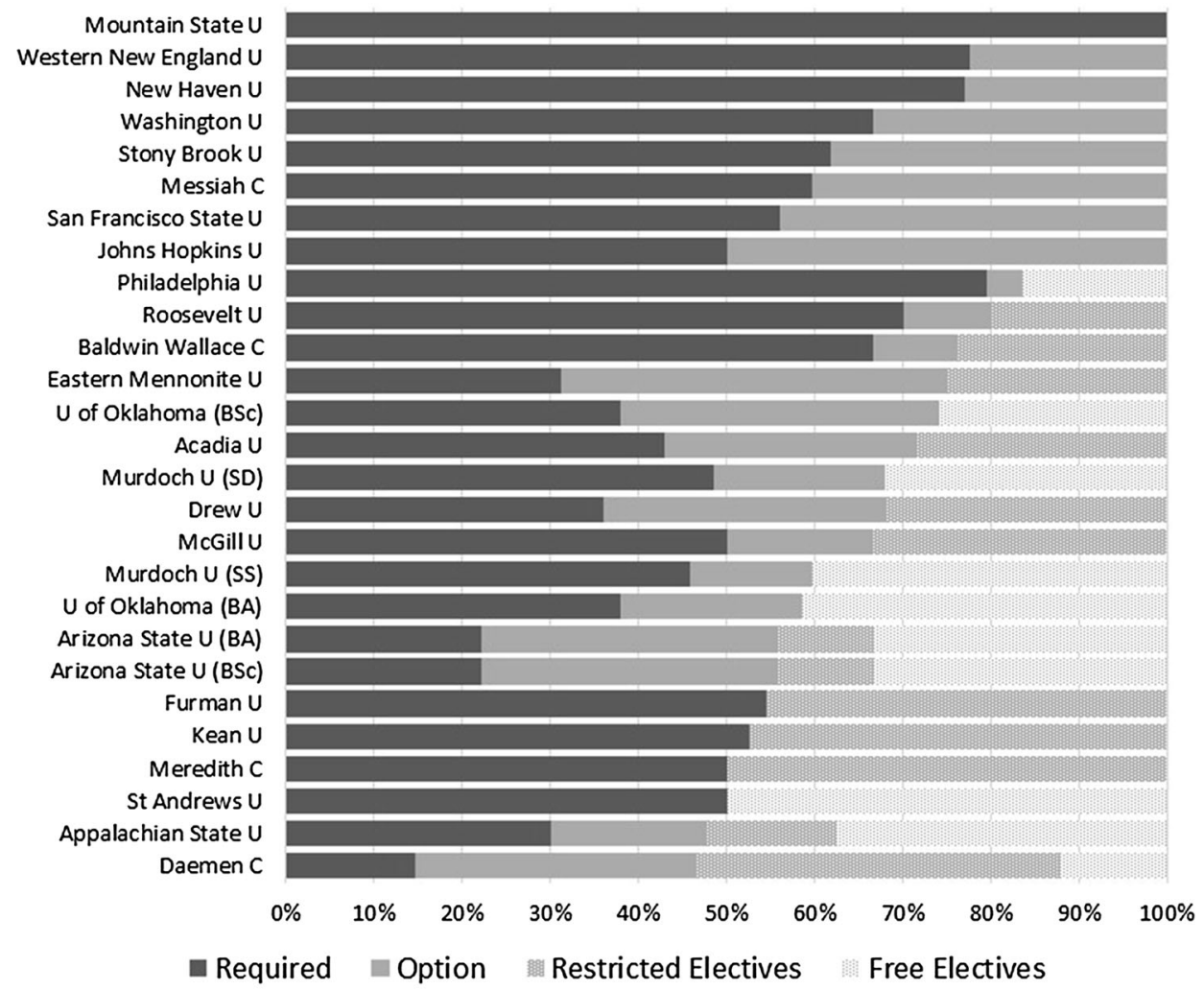

b

\section{Course Structure of Master's Programmes}

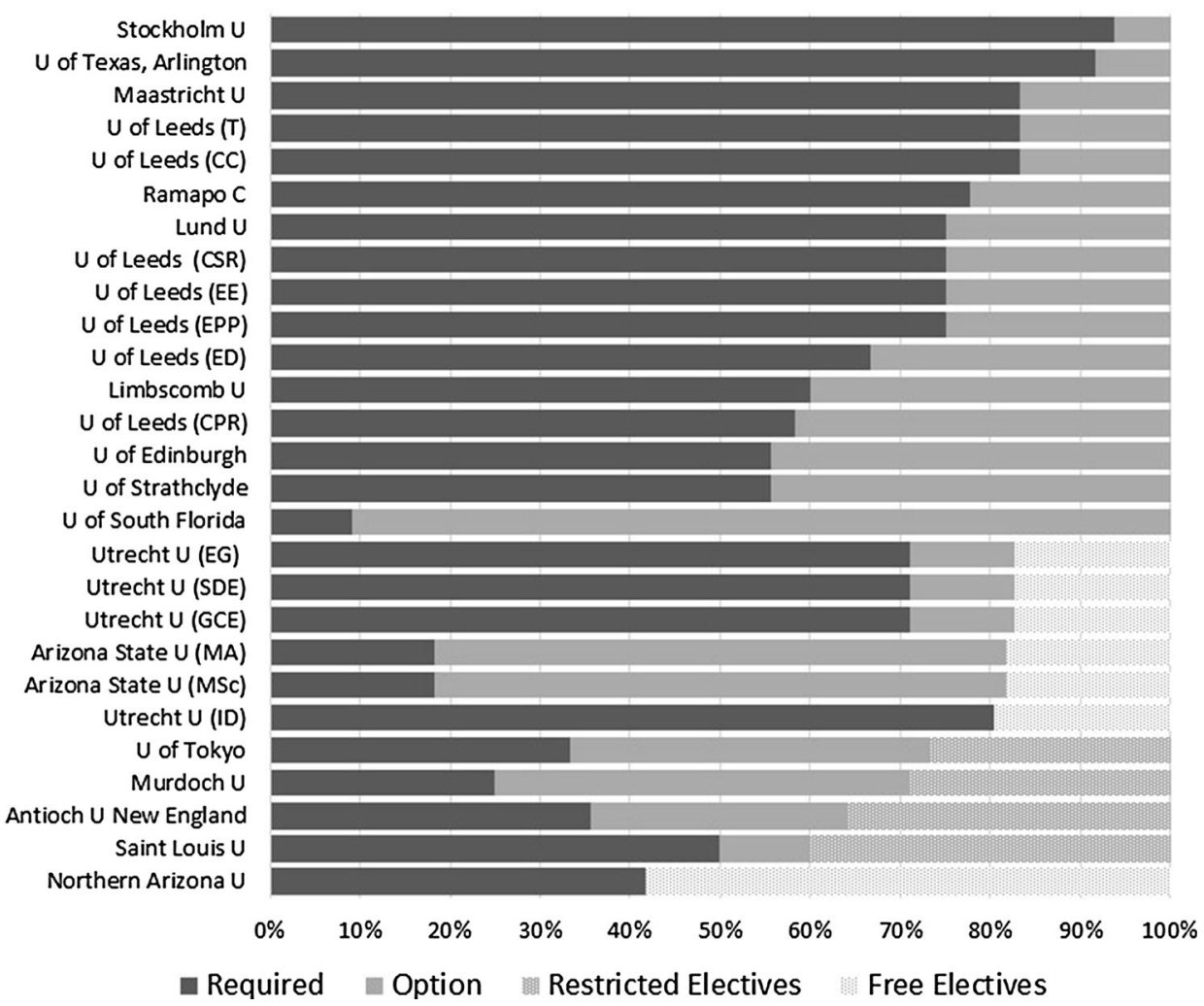




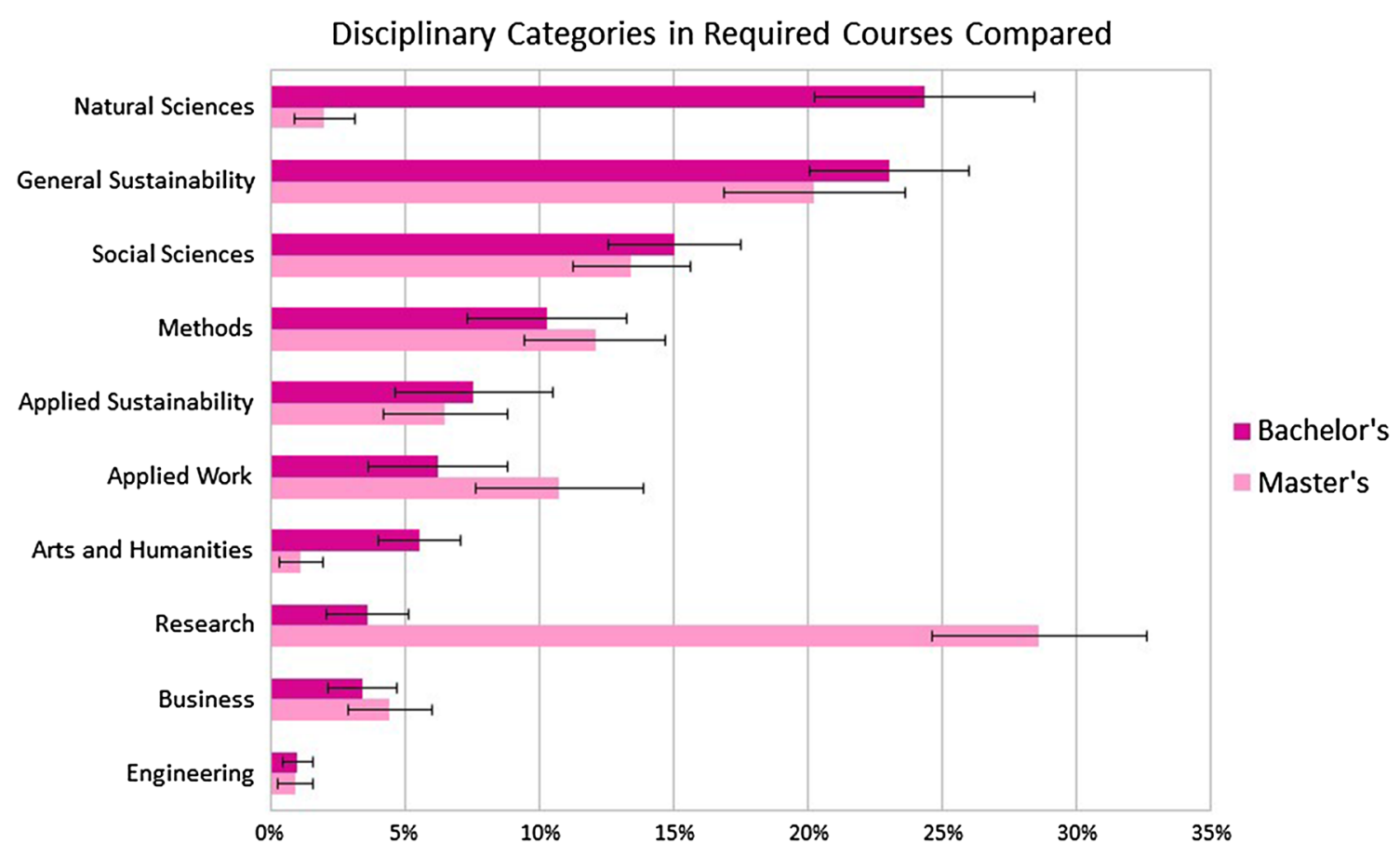

Fig. 3 The average content of required courses by disciplinary category, as a percentage of total required program content, within all bachelor's or master's programs. Course content was categorized from course titles and descriptions on program websites (following

the process shown in Fig. 1). Data on credits were taken from program summaries on program websites. Error bars show standard error for all programs within the bachelor's $(N=27)$ or master's $(N=27)$ level

master's level; if we excluded the climate course from the Leeds University programs in the analysis, the climate, energy, water, and industry core course subject areas were roughly equally represented $(\sim 20 \%)$ among the master's programs.

Within the natural science category, the environmental science and ecology core course subject areas were the most common among the bachelor's programs (present in 78 and $52 \%$ of the programs, respectively) (Fig. 4a). At the master's level, no single natural science core course subject area was found among more than $20 \%$ of the programs (Fig. 4b); climate science was the most common (present in $19 \%$ of the programs, although all of these five programs were within the seven different sustainability degree programs at Leeds University). Within the social science category, the most common core course subjects in bachelor's programs were economics (59\%) and policy and governance (56\%). For master's programs, the most common core course subjects were policy and governance (78\%) and development (44\%).

\section{Reading lists}

Of our total sample of 54 programs, $83 \%$ (45 programs) featured a core course in sustainability. At some universities, the same core course was shared between more than one program, resulting in a total of 32 unique core sustainability courses. We contacted the instructors of these 32 core sustainability courses, and received 25 responses with syllabi, 22 of which included reading lists. The 22 courses with reading lists in our sample are core courses in a total of 32 programs (those marked with an asterisk in Table 2; those which share a core course with other programs at the same university share a letter). The reading lists showed a wide diversity of literature in the field; there were only three works (and multiple works by an additional two authors) appearing in more than two courses (Table 3).

\section{Discussion}

\section{Curriculum structure}

In our examination of 54 higher education programs in sustainability, we found that core courses made up the majority of the curriculum in all but two bachelor's programs and all but one master's program, with the overall proportion of core courses within a program varying from 42 to $100 \%$. Given this majority, we are confident that our analysis of the core course breadth and subject areas adequately captures and reflects the essence and fundamental content of these sustainability programs. We speculate that the higher proportion of core courses within master's programs compared to bachelor's programs is similar 


\section{a Bachelor's}

Average "Requiredness" of Programs

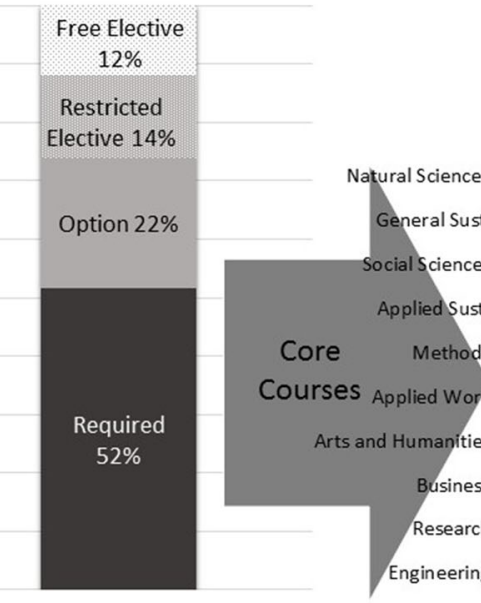

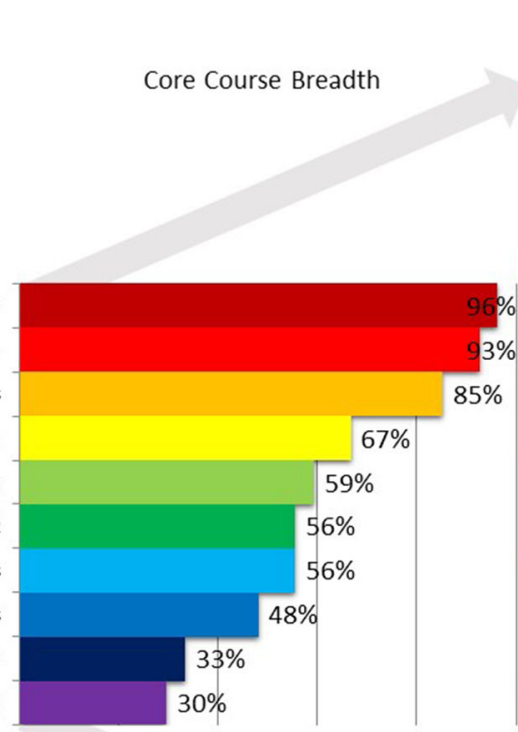

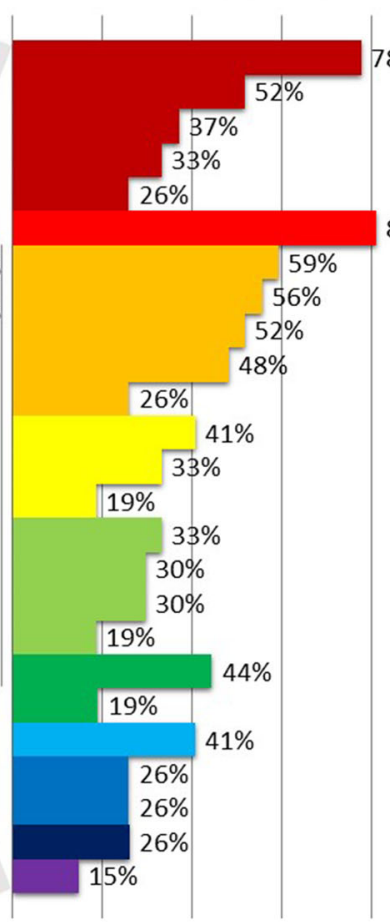

$78 \%$

Environmental Science

- Ecology

- Chemistry

aiology

maths

$81 \%$ Intro to Sustainability

= Economics

= Policy + Governance

= Development

In Sociology

Environmental Sociology

Urban

Energy

an Food

In Statistics

= GIS

nesearch Methods

= Modeling

- Internship

- Applied Project

a Ethics

- Organisational Studies

nanagement

- Capstone Project

v Planning

\section{b Master's}

Average "Requiredness" of Programs

Free Elective 6\%

Restricted Elective 5\%
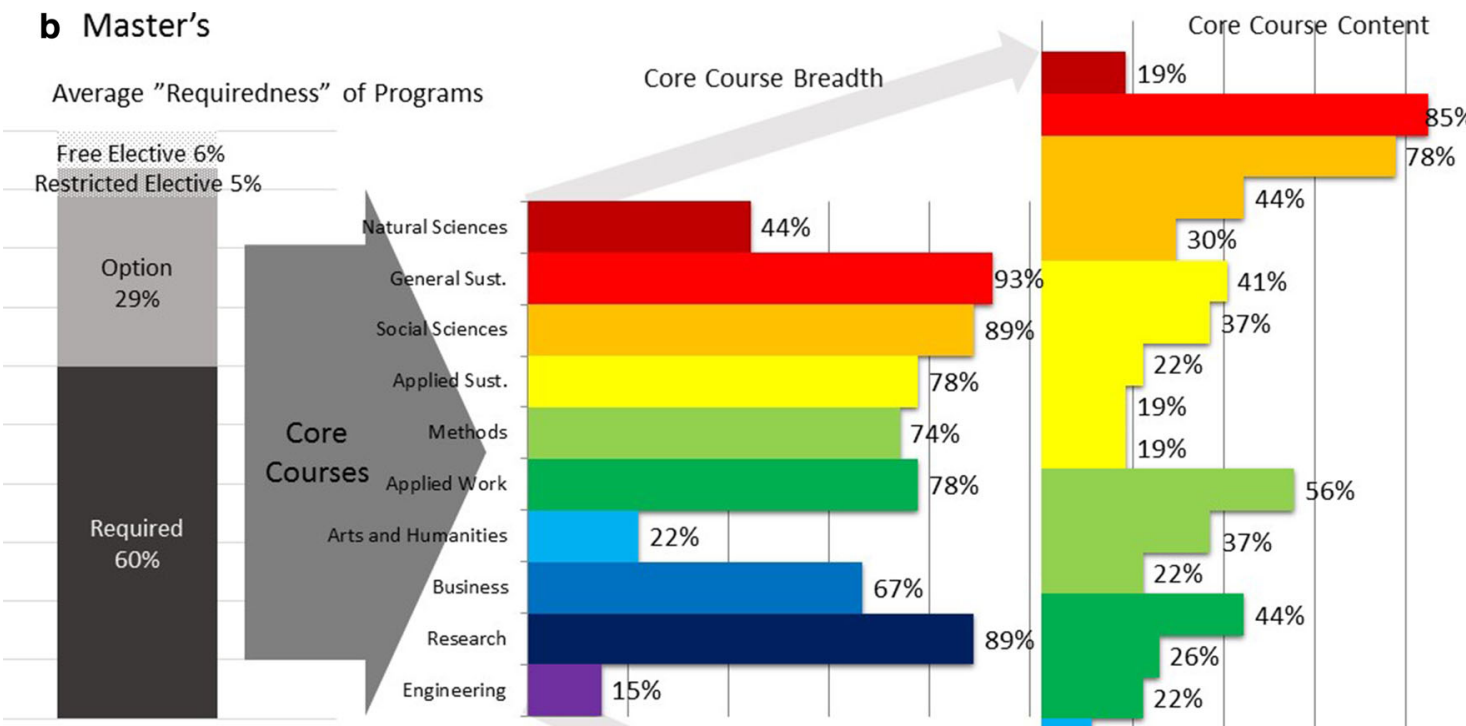

Climate Science

- Intro to Sustainability

$78 \%=$ Policy + Governance

anevelopment

= Economics

Climate

Enterprise

Energy

Industry

Water

a Research Methods

Quantitative Methods

Modeling

Applied Project

Internship

- Fieldwork

Ethics

m Business Sustainability

- Thesis

- Research Project

- Energy systems

Fig. 4 The breakdown of core (required and option) courses in bachelor's (a) and master's (b) programs, in terms of breadth (into one of ten disciplinary categories) and content (with the most widely offered course subject areas within each disciplinary category shown on the right). Data are taken from course summaries and categorized from course titles and descriptions, all from program websites. The numbers reflect the percentage of programs (out of $N=27$ for both bachelor's and master's programs) offering a core course in the respective disciplinary categories and course subject areas 
Table 3 The most common authors and their associated publications appearing on the reading lists of syllabi available for introductory or core sustainability courses at both Bachelor's and Master's level $(N=22$ core sustainability courses taught in 32 degree programs). Where multiple publications are listed, the numbers refer to the total for each author

\begin{tabular}{|c|c|c|c|}
\hline Author(s) & $\begin{array}{l}\text { Courses } \\
\text { featured }\end{array}$ & Title & Year \\
\hline Hardin & 6 & The tragedy of the commons & 1968 \\
\hline $\begin{array}{l}\text { Rockström } \\
\text { et al. }\end{array}$ & 4 & A safe operating space for humanity & 2009 \\
\hline \multirow[t]{3}{*}{ Folke } & \multirow[t]{3}{*}{4} & $\begin{array}{l}\text { Principles of ecosystem } \\
\text { stewardship: resilience-based } \\
\text { natural resource management in a } \\
\text { changing world (Chapin et al.) }\end{array}$ & 2009 \\
\hline & & $\begin{array}{l}\text { Adaptive co-management for } \\
\text { building resilience in social } \\
\text { ecological systems (Olsson et al.) }\end{array}$ & 20 \\
\hline & & $\begin{array}{l}\text { Resilience and sustainable } \\
\text { development: building adaptive } \\
\text { capacity in a world of } \\
\text { transformation (Folke et al.) }\end{array}$ & 2002 \\
\hline Holling & 3 & $\begin{array}{l}\text { Resilience and stability of } \\
\text { ecological systems }\end{array}$ & 197 \\
\hline \multirow[t]{2}{*}{$\begin{array}{l}\text { Miller and } \\
\text { Spoolman }\end{array}$} & \multirow[t]{2}{*}{3} & $\begin{array}{l}\text { Living in the environment: } \\
\text { principles, connections and } \\
\text { solutions }\end{array}$ & 20 \\
\hline & & $\begin{array}{l}\text { Environmental problems, their } \\
\text { causes, and sustainability in } \\
\text { Environmental Science }\end{array}$ & 20 \\
\hline
\end{tabular}

within other disciplines and may also be a result of the origins of the bachelor's and master's sustainability programs. Based on information available on program websites, many bachelor's programs in sustainability appear to have evolved from existing programs or departments in which a few core courses in sustainability are developed, supplemented by electives comprised of existing courses taught by faculty in their respective tenure-line departments across disciplines. In contrast, master's programs are more likely to be created as a stand-alone interdisciplinary program from the start, often through an academic center or a department, with a specifically designed, more limited, and more prescribed curriculum. Bachelor's programs also typically require more curricular flexibility so that students can fulfill general education requirements within a reasonable period of time, while master's programs do not include general education requirements and tend to be more focused, with students moving through specified courses as a cohort.

\section{Core course breadth}

Within the core courses, there was surprisingly little coherence both between and within the bachelor's and master's programs in terms of the subjects of study included in a sustainability degree. Based on the literature (Tilbury 1995; Kates et al. 2001; Clark and Dickinson 2003; Brundiers et al. 2010; Martens et al. 2010; Yarime et al. 2012), we expected more coherence between the different programs, and a greater and more balanced breadth across the ten different disciplinary categories within each program. We would not necessarily expect every program to contain core courses spanning all ten categories, but it is surprising there was no single category present in all programs. The fact that programs on average included six of the ten disciplinary categories within their core courses highlights the inherent breadth of the field and the programs, but the identity and distribution of these disciplines within the curricula varied immensely (Fig. 4). This is all the more striking given that we considered several degree programs from one university (Leeds University) with similar requirements as separate programs for this analysis.

We found distinct differences between the core course breadth and subject areas between the master's and bachelor's programs. Master's programs in sustainability were heavily research-based, with self-directed research and applied work contributing over $40 \%$ of required course time on average (Fig. 3), and core course emphasis on the social sciences and general and applied sustainability (Fig. $4 \mathrm{~b}$ ), but very limited inclusion of the natural sciences and arts and humanities within the required curriculum (Fig. 3). Bachelor's programs in sustainability, in contrast, emphasized core courses in the natural sciences, general sustainability, and social sciences (Fig. 4a), with less research in required courses (only $4 \%$ ) and applied course work, but also limited inclusion of arts and humanities within the required curriculum (Fig. 3). The disparity in the proportion of core credit hours for research courses between master's and bachelor's programs is not surprising given the nature of the degrees, but the different emphasis on disciplinary topics is.

\section{Natural science}

The lack of natural science core courses at the master's level is certainly disconcerting and somewhat surprising given that previous studies (Sherren 2006, 2008) found a heavy biological and ecological orientation for environmental sustainability programs, with insufficient attention to human and societal aspects of sustainability. It should be noted that Sherren's selection criteria were not restricted to programs with sustainability in the title, but rather programs that addressed sustainability in some way, including incorporating sustainability into existing disciplines. Some of the apparent scarcity of natural sciences may be due to the fact that in some programs the natural science components are covered within the general sustainability or 
applied sustainability courses instead of as stand-alone natural science courses. This is something our course coding system cannot capture, but we question the ability of such treatment alone to adequately impart an appreciation of natural science epistemology and methodology, especially to students with no natural science background, to intentionally rather than tacitly integrate the disciplines. Therefore, it is surprising that the master's programs were not more balanced between natural and social sciences in their course subjects. It may be the case that many master's programs in sustainability evolved from departments, programs, or faculty with backgrounds in the social sciences, possibly as a counter-response to the perceived exclusion or marginalization of social sciences in sustainability science (Jerneck et al. 2010).

Nevertheless, given that none of the master's programs with sufficient information on the program webpage to assess pre-entry requirements ( $N=23$ out of 27) had any natural science prerequisites, it appears that students could complete an advanced degree in sustainability without ever having taken a college-level course in natural science. This possibility raises concerns over whether all graduates of these programs, particularly those with social science or humanities backgrounds, would be able to understand and effectively articulate, employ or critique the natural science basis of sustainability problems, such as the Planetary Boundaries approach by Rockström et al. (2009), or adequately contribute to key sustainability issues like climate change in the context of sustained attack on the natural scientific basis of such issues (Oreskes 2010; McCright and Dunlap 2011). The lack of core natural science courses within some master's programs in sustainability could lead to difficulties in communication and mutual understanding between scholars and practitioners of sustainability, and is a deficit that needs to be addressed as these programs evolve and mature.

\section{Arts and humanities}

The arts and humanities were substantially under-represented within the core sustainability curricula, comprising only $6 \%$ of the bachelor's and only $1 \%$ of the master's required content (Fig. 3), with only $22 \%$ of master's and just over half $(56 \%)$ of bachelor's programs offering a core course in this category (Fig. 4). Sherren (2008) also found few arts and humanities courses in sustainability programs, in particular noting that the few programs in her study that made explicit reference to sustainability lacked courses in philosophy.

These gaps are concerning, because sustainability is a normative, value-laden endeavor in which the world is often described in terms of how it ought to be, for example, to pursue social and economic development (Rockström et al. 2009). The moral and ethical debates that are the essence of much of the arts and humanities are certainly important for the development of the normative competencies for sustainability suggested by Wiek et al. (2011). Consequently, some training and background within this category are important for assessing unsustainable systems, collectively creating visions for future models of sustainability (Wiek et al. 2011), and helping graduates make value-laden decisions and interact with diverse cultural and belief systems. Given the already heavy course loads and time restrictions of most undergraduate and graduate programs, it may be difficult to require entire sustainability courses in philosophy, literature, or ethics, but the character of sustainability suggests their inclusion to some extent would be valuable, for example in option and elective courses.

\section{Course subjects}

The preference within bachelor's programs for core courses in the natural sciences, specifically environmental sciences and ecology, is somewhat expected given that most bachelor's programs in sustainability appear to have evolved from an existing environmental studies or science program, as evident in the curriculum and names of the program degrees, six out of 27 of which are "Environmental Sustainability" (Table 2). For most institutions, it is financially and often logistically prohibitive to develop a new stand-alone, interdisciplinary sustainability department at the bachelor's level; instead, new programs are developed from existing programs.

Policy and government, economics, and development courses dominate the social science core offerings at both the bachelor's and master's levels. Sociology at the master's level, and anthropology and psychology at both levels, are surprisingly absent and may reflect what Jerneck et al. (2010) identified as the tendency in sustainability science to afford less space to approaches that question the assumptions of western modernity. While the lack of natural science in master's programs could raise problems for graduates, similarly the lack of critical social sciences ignores a long tradition of theorizing about social patterns and change that will be essential to overcome problems of unsustainability. In the medium term, the omission of natural sciences, certain social sciences, and arts and humanities may also reinforce existing epistemological gaps in university departments, if students of varying backgrounds are not encouraged to gain appreciation and ability across disciplinary divides. The same goes for faculty involved in the organization and teaching of curricula.

Within the applied sustainability category, the only popular course topic shared by programs at both levels was energy. Courses in climate were most prevalent in master's programs, and courses in urban systems were most popular 
in bachelor's programs. Interestingly at the master's level, courses within enterprise were more common than more traditional, widely discussed sustainability topics like water, food, and energy, which fits with the more businessoriented and more social science-focused approach to sustainability evident in many master's programs. Typically, master's programs required more courses in business management and organizational studies, and from the analytical social sciences such as policy, development, and economics, compared to bachelor's programs. These differences suggest that master's and bachelor's programs may be, in general, approaching sustainability from fundamentally different perspectives.

Less than a quarter of core sustainability courses shared any one text in their reading material, suggesting that there is currently no widely agreed upon foundational literature for teaching sustainability. In particular, it is striking that, of the most widely used texts (Table 3), several are more than 40 years old, and only two include the word "sustainable" or "sustainability" in their titles (although four of the eight texts include "resilience"). Further, none of the more recent literature widely cited within the scholarly field of sustainability (e.g., Kates et al. 2001; Clark and Dickson 2003) is currently being widely used in teaching sustainability. This divergence between the scholarly literature and the texts being used in educational programs shows that the field is taking a diverse set of content and institutional approaches under the heading of sustainability. While this may benefit the creativity of the field, there may be a useful role for a foundational text for education in sustainability to ensure some coherence between programs. One option is presented by the reading lists supplied in the Ruffolo Curriciulum on Sustainability Science (Andersson et al. 2008).

\section{Disciplinary vs. interdisciplinary content}

Overall, courses within the applied sustainability, applied work, and research categories are more prevalent in master's programs than in bachelor's programs, which contain more disciplinary courses in the natural sciences, and arts and humanities (Fig. 4). This disparity may explain the lack of stand-alone courses in natural sciences, arts and humanities, and critical social sciences at the master's level, with these approaches being covered in these interdisciplinary, more generalist courses. Moreover, it raises the question of how best to integrate the diverse fields that contribute to sustainability education. The approach in master's programs appears to favor the integration of disciplines in interdisciplinary and applied or research courses, while bachelor's programs service the interdisciplinary nature of sustainability through existing disciplinary courses. Though the varying approaches taken may reflect the nature of these degrees in general, in both instances it must also be appropriate to the specific requirements of sustainability education. It remains unclear whether discipline-based bachelor's programs can adequately meet the requirements of sustainability education. More broadly, this analysis raises the question as to what is the appropriate approach to disciplinary content. Presumably, what is required is a balance between foundational courses in certain core subjects in various disciplinary areas and their integration in inter- and transdisciplinary courses. The evaluation of this approach would require examination of the programs as a whole, including the progression of the program throughout the degree period and the actual teaching methods employed.

Disparity between program curricula and literature on sustainability

We have shown that there is a discrepancy between what is being offered in sustainability programs in higher education and how sustainability as an academic field is described in the literature (Clark and Dickson 2003; Komiyama and Takeuchi 2006; Hansmann 2010; Bacon et al. 2011), particularly in integrating natural and social sciences. The disciplinary gaps and omissions we have identified create limitations for graduates of these programs to fully engage in sustainability problem-solving. We are not suggesting that sustainability degrees should converge on a specific, precise curriculum. Rather, we suggest that intentionally designing the content of sustainability education using fundamental disciplinary building blocks from the natural and social sciences and arts and humanities would help ensure the diversity of the field while promoting coherence. We believe that some shared foundations between programs are necessary for sustainability to develop into a mature scientific program that is recognizable across universities and understood by academics, employers, and civil society. Further, the development, redevelopment, and continuation of programs in sustainability form an important part of its institutionalization as an academic field, because to a certain extent, what counts in society as legitimate knowledge within a field is defined by the curricular content of programs in that field (Meyer 1977). We argue that education programs in sustainability would benefit from somewhat increased alignment and a more closely shared vision, following the literature on the scholarly practice of sustainability. However, we recognize that some may be critical of the idea of a narrowly prescribed field, preferring that sustainability continues to be open to diversity and adapted to specific contexts. A middle ground would be for programs to explicitly articulate what their vision of sustainability is to engage in valuable debate and discussion about the content and motivation of sustainability education. 
Barriers and recommendations

There are several possible explanations for the current program structures in sustainability, with their lack of natural science at the master's level and a neglect of the arts and humanities and critical social sciences such as sociology, anthropology, and psychology at both levels. One explanation could be related to the developmental history of these programs, particularly whether they arise from a natural science, social science, or arts and humanities department. Another cause may be that program structure reflects various other organizational, pedagogical, and financial limitations that affect all universities as economic organizations (Gumport 2000; Etzkowitz 2001). Or the current program structure may be especially influenced by the particular characteristics of sustainability as a relatively new field, especially its inter- and transdisciplinary aspirations. Moore (2005a) has pointed to the disciplinary environment of most universities and internal competition, as well as poor criteria for evaluation and unclear priority-setting and decisionmaking, as factors that limit program design. Furthermore, Sherren et al. (2010) highlight challenges including the diffuse nature and broad scope of sustainability, financial and organizational constraints inherent in the process of curriculum design, and issues that arise from the social process of curriculum design, staff motivation and commitment. Such structural barriers could well explain the findings in our study.

Therefore, efforts to develop programs in sustainability ought to acknowledge and address some of these potentially challenging structural barriers. The disciplinary structure of universities is ingrained and instantiated in buildings, faculties, academic and research programs that all act to preserve its momentum. Universities, like all organizations, are limited by temporal, financial, and human resources, and exist in a competitive market. Bringing about new disciplinary and departmental constellations, staffed with new generations of interdisciplinary researchers and teachers, and securing resources to support innovative programs and learning experiences will require political will from university leadership. To foster this development, key university actors and institutions must recognize the benefits of providing sustainability education, as well as research environments, appropriate to the problems faced by society, which can attract students and funding. Nevertheless, change will not necessarily come from the top. All those involved in curricula design can endeavor to tackle structural barriers at the level at which they encounter them, whether this be in course directors collaborating across epistemic and disciplinary divides, or teachers finding novel ways of integrating environmental, social, and economic elements in a transformational mode, within and beyond the classroom. The classroom can thus become an exemplary space that informs broader university institutions, and from which a new paradigm in education can evolve.

\section{Further research}

While this study was an important first step in compiling and analyzing existing higher education programs focused on sustainability, several improvements could be made in future research. First, the inclusion of programs for analysis could be expanded, both in the source from which programs are drawn, and the criteria for inclusion. This research was limited to programs in the SSPP database at the time of analysis in early 2012; a subsequent review could be expanded in the future to include new programs, including those not listed in the SSPS database at the time of our study. For example, a more recent report by the National Council for Science and Education (see Vincent et al. 2013) found 109 programs in the US that appear to match our criteria. Because an analysis of the field (as well as students seeking programs to which to apply) is likely to rely on information that programs present themselves, it is important that programs maintain complete and up-to-date individual websites, as well as consider participating in networks for sustainability education, which would also support more collaboration between programs to share information on their curricular content and focus. In order to get a more general view of the state of academic programs that address sustainability at some level, this analysis of narrow-field sustainability, defined by programs that explicitly put sustainability in their titles, could also be broadened to include more programs that self-identify as focusing on sustainability, although their degree titles are granted in other fields such as earth systems or environmental science. However, since we found such a diverse array of approaches within programs that grant degrees in sustainability, such an analysis might be too broad to reveal useful patterns, and would not necessarily represent the emerging meaning of sustainability in both academia and society.

Other extensions to this research could focus on deeper analysis of the subjects taught within these programs, and how they compare to programs in more established or traditional disciplines, since content plays a central role in the establishment and definition of a field. This could include a refinement of the classification system for categorizing courses, where the ten disciplinary categories we established could be more systematically defined based on their constituent course subjects. The variety of disciplinary content in these programs (e.g., the natural and social sciences and the humanities) involves the confluence of different epistemologies and methodologies, and typically utilizes teaching staff with different departmental and disciplinary backgrounds and affiliations. Therefore, 
educational institutions do more than impart competencies to individuals; they structure categories of knowledge, what is legitimate within them and thus influence how society uses knowledge (Meyer 1977). Curricula provide credentials to individuals on the basis of which they gain the legitimacy to operate in certain economic, political, and social sectors (Meyer 1977). By looking at the disciplinary content of these degrees in sustainability, we examine not only the subject matter that students are exposed to, but also how sustainability as a concept is being institutionalized through formal education. To have the greatest impact on society, graduates should indeed be equipped with the appropriate disciplinary knowledge (and interdisciplinary competencies). Furthermore, we argue, what makes up a sustainability degree and thus becomes institutionalized in society as legitimate sustainability knowledge, ought to be both coherent and suited to its purpose, as understood and developed in theoretical and practical work and discussed in sustainability literature.

Finally, it would also be useful to include an assessment of the teaching methods and approaches in the courses, particularly the interdisciplinary, applied, and research courses, to move beyond an analysis of what is being taught to understand how it is being taught. This approach would allow an assessment of whether sustainability in higher education is including the communication and strategic skills that are important for sustainability science, as well as bridging topics from natural and social sciences, which our disciplinary categorization system cannot capture. Further research could also investigate the teaching and learning approaches and the motivation behind program design in more detail, through in-depth interviews or surveys with core faculty, administrators, and students. Such an approach would be necessary to evaluate, for example, if and how each of the five core competencies for sustainability identified by Wiek et al. (2011) are being taught in each program. Continued research and alignment with practice in new program design and in program updates will be important to ensure that education in the rapidly growing field of sustainability lives up to its promising potential.

\section{Conclusions}

With the establishment of sustainability as a recognized academic field, sustainability degree programs in higher education have emerged and likely will continue to rapidly proliferate. This study evaluated the state of sustainability degree programs by analyzing 54 sustainability programs in higher education based on the curricular structure, the breadth of the core courses, and the core course subject areas. While bachelor's programs were, on average, more flexible than the master's programs, core courses made up the majority of both curricula. Both sets of programs showed a high degree of disciplinary variety within these core courses, which on average were drawn from six of the ten disciplinary categories we studied. However, they showed surprisingly little curricular coherence between programs with the identity, inclusion, and distribution of core courses in these disciplinary categories within the curricula. In fact, there was no single disciplinary category present, or subject offered within any disciplinary category, in all programs.

This lack of consistency in curricular content is a potential cause for concern and suggests that different programs in sustainability are taking different approaches to curricular content, with no core set of disciplines or subjects that are universally recognized as essential to sustainability degree programs, in contrast with the integration of natural and social sciences proposed in the literature. The high degree of variability among the disciplinary categories and subject areas within sustainability programs could simply reflect the early stage of development of the academic field of sustainability, the variety of backgrounds from which the programs have developed, the currency of sustainability as a marketable program, or differences of opinion over what it is that sustainability should be.

However, if sustainability is to develop into a mature scientific program that is recognizable across universities and by society in general, we would expect increasing agreement on shared foundations in the field to be reflected in curricula that share core elements. Scholars, educators, and students must decide how diverse the field of sustainability aims to be, and what approaches to disciplinary content are most relevant. If this remains ambiguous, the already contested concept of sustainability may risk losing its meaning. While the field of sustainability is still developing, we have argued that higher education programs could benefit from more coherence among programs in their fundamental disciplinary makeup and thoughtful alignment with the interdisciplinary principles espoused in the literature on sustainability scholarship. Such alignment in sustainability-focused programs, in addition to incorporating sustainability principles into existing disciplines, would help educate the next generation of sustainability scholars and scientists to tackle some of today's most pressing problems.

Acknowledgments The authors gratefully acknowledge The Swedish Research Council Formas through the RESULTS grant for supporting Open Access publication. The authors wish to thank three anonymous reviewers for helpful commentary in improving the manuscript.

Open Access This article is distributed under the terms of the Creative Commons Attribution License which permits any use, distribution, and reproduction in any medium, provided the original author(s) and the source are credited. 


\section{References}

Andersson K, Burns M, Bursztyn M, Douglas AH, Laudati A, Matus $\mathrm{K}$, McNie E (2008) The Ruffolo curriculum on sustainability science: 2008 Edition. CID Graduate Student and Research Fellow Working Paper No. 32. Center for International Development at Harvard University, December 2008

Australian Bureau of Statistics (1998) Australian Standard Research Classification. http://www.abs.gov.au/ausstats/abs@.nsf/0/2D3B 6B2B68A6834FCA25697E0018FB2D?opendocument. Accessed 24 Jan 2012

Bacon C, Mulvaney D, Ball T, DuPuis E, Gliessman S, Lipschutz R, Shakouri A (2011) The creation of an integrated sustainability curriculum and student praxis projects. Int J Sustain High Educ 12(2): 193-208

Brundiers K, Wiek A (2013) Do we teach what we preach? An international comparison of problem and project based learning courses in sustainability. Sustainability 5(4):1725-1746

Brundiers K, Wiek A, Redman CL (2010) Real-world learning opportunities in sustainability: from classroom into the real world. Int J Sustain High Educ 11(4):308-324

Chapin FS, Kofinas GP, Folke C (eds) (2009) Principles of ecosystem stewardship. Springer, New York

Clark WC (2007) Sustainability science: a room of its own. Proc Natl Acad Sci 104:1737-1738

Clark WC, Dickson NM (2003) Sustainability science: the emerging research program. Proc Natl Acad Sci USA 100(14):8059-8061

Etzkowitz H (2001) The second academic revolution and the rise of entrepreneurial science. Technol Soc Mag, IEEE 20(2):18-29

Folke C, Carpenter S, Elmqvist T, Gunderson L, Holling CS, Walker B (2002) Resilience and sustainable development: building adaptive capacity in a world of transformations. AMBIO: A J Hum Environ 31(5):437-440

Gumport PJ (2000) Academic restructuring: organizational change and institutional imperatives. High Educ 39(1):67-91

Hansmann R (2010) "Sustainability Learning": an introduction to the concept and its motivational aspects. Sustainability 2:2873-2897

Hardin G (1968) The tragedy of the commons. Science 162:1243-1248

Higher Education Statistics Agency (2012) Joint academic coding system v 1.7. http://www.hesa.ac.uk/dox/jacs/JACS_complete. pdf. Accessed 24 Jan 2012

Holling CS (1973) Resilience and stability of ecological systems. Annu Rev Ecol Syst 4:1-23

Iyer-Raniga U, Andamon M (2012) Sustainability education in the engineering and built environment curriculum: the case for the Asia-Pacific ICERI2012 proceedings. http://www.ias.unu.edu/ prospernet/wp-content/uploads/2012/09/Iyer-Raniga_Andamon_ Paper_id 730_25456_Final.pdf

Jerneck A, Olsson L, Ness B, Anderberg S, Baier M, Clark E, Hickler $\mathrm{T}$ et al (2010) Structuring sustainability science. Sustain Sci 6(1):69-82. doi:10.1007/s11625-010-0117-x

Journal for Sustainability-SSPP (2012) Academic programs in sustainability: a growing database of educational institutions offering degree granting sustainability programs worldwide. http://sspp.proquest.com/sspp_institutions/display/universitypro grams. Accessed 24 Jan 2012

Kates R, Clark W et al (2001) Sustainability science. Science 292(5517):641-642

Khagram S, Nicholas KA, MacMynowski D, Warren J, Richards E, Oleson K, Kitzes J, Katz R, Hwang R, Goldman R, Funk J, Brauman K (2010) Thinking about knowing: conceptual foundations for interdisciplinary environmental research. Environ Conserv 37(4):388-397

Komiyama H, Takeuchi K (2006) Sustainability science: building a new discipline. Sustain Sci 1:1-6
Martens P, Cörvers R, Roorda N (2010) Sustainability, science and higher education: the need for new paradigms. Sustain J Rec 3(5):294-303

McCright AM, Dunlap RE (2011) Cool dudes: the denial of climate change among conservative white males in the United States. Glob Environ Change 21(4):1163-1172

Meyer J (1977) The effects of education as an institution. Am J Sociol 83(1):55-77

Miller GT, Spoolman SE (2009) Living in the environment: principles, connections, and solutions. Cengage Learning

Miller GT, Spoolman SE (2010) Environmental problems, their causes, and sustainability. In: Miller GT, Spoolman SE (eds) Environmental science, 13th edn. Brooks/Cole, Belmont, California, pp 5-13

Moore J (2005a) Barriers and pathways to creating sustainability education programs: policy, rhetoric and reality. Environ Educ Res 11(5):537-555

Moore J (2005b) Seven recommendations for creating sustainability education at the university level: a guide for change agents. Int J Sustain High Educ 6(4):326-339

National Centre for Education Statistics (2012) Classification of Instructional Programs (CIP 2000). http://nces.ed.gov/pubs2002/ cip2000/index.asp. Accessed 24 Jan 2012

Olsson P, Folke C, Berkes F (2004) Adaptive comanagement for building resilience in social-ecological systems. Environ Manag 34(1):75-90

Oreskes N (2010) Defeating the merchants of doubt. Nature 465:10-11

Rockström J et al (2009) A safe operating space for humanity. Nature 461:472-475

Segalàs J, Ferrer-Balas D, Mulder K (2008) Conceptual maps: measuring learning processes of engineering students concerning sustainable development. Eur J Eng Educ 33:297-306. doi:10. 1080/03043790802088616

Sherren K (2005) Balancing the disciplines: a multidisciplinary perspective on sustainability curriculum content. Aust J Environ Educ 21:97-106

Sherren K (2006) Core issues: reflections on sustainability in Australian university coursework programs. Int J Sustain High Educ 7(4):400-413

Sherren K (2008) Higher environmental education: core disciplines and the transition to sustainability. Aust $\mathrm{J}$ Environ Educ 15:190-196

Sherren K, Robin L, Kanowski P, Dovers S (2010) Escaping the disciplinary straitjacket: curriculum design as university adaptation to sustainability. J Glob Responsib 1(2):260-278

Sibbel A (2009) Pathways towards sustainability through higher education. Int J Sustain High Educ 10(1):68-82

Tilbury D (1995) Environmental education for sustainability: defining the new focus of environmental education in the 1990s. Environ Educ Res 1(2): 195-212

van der Leeuw S, Wiek A, Harlow J, Buizer J (2012) How much time do we have? Urgency and rhetoric in sustainability science. Sustain Sci 7(1):115-120

Vincent S, Bunn S, Stevens S (2013) Sustainability education: results from the 2012 census of U.S. Four Year Colleges and Universities. National Council for Science and Education, Washington

Wiek A, Withycombe L, Redman CL (2011) Key competencies in sustainability: a reference framework for academic program development. Sustain Sci 6(2):203-218

Yarime M, Trencher G, Mino T, Scholz RW, Olsson L, Ness B, Frantzeskaki N, Rotmans J (2012) Establishing sustainability science in higher education institutions: towards an integration of academic development, institutionalization, and stakeholder collaborations. Sustain Sci 7(1):101-113 